\title{
Neuroleptic sensitivity in patients with senile dementia of Lewy body type
}

\author{
Ian McKeith, Andrew Fairbairn, Robert Perry, Peter Thompson, Elaine Perry
}

\begin{abstract}
Objective - To determine the outcome of administration of neuroleptics to patients with senile dementia of Lewy body type confirmed at necropsy.

Design-Retrospective analysis of clinical notes blind to neuropathological diagnosis.

Setting-Specialist psychogeriatric assessment units referring cases for necropsy to a teaching hospital neuropathology service.

Patients -41 elderly patients with diagnosis of either Alzheimer type dementia $(n=21)$ or Lewy body type dementia $(n=20)$ confirmed at necropsy.

Main outcome measures-Clinical state including extrapyramidal features before and after neuroleptic treatment and survival analysis of patients showing severe neuroleptic sensitivity compared with the
\end{abstract} remainder in the group.

Results-16 (80\%) patients with Lewy body type dementia received neuroleptics, $13(81 \%)$ of whom reacted adversely; in seven (54\%) the reactions were severe. Survival analysis showed an increased mortality in the year after presentation to psychiatric services compared with patients with mild or no neuroleptic sensitivity (hazard ratio $2 \cdot 70$ (95\% confidence interval 2.50-8.99); $\left(\chi^{2}=2.68, p=0.05\right)$. By contrast, only one (7\%) of 14 patients with Alzheimer type dementia given neuroleptics showed severe neuroleptic sensitivity.

Conclusions-Severe, and often fatal, neuroleptic sensitivity may occur in elderly patients with confusion, dementia, or behavioural disturbance. Its occurrence may indicate senile dementia of Lewy body type and this feature has been included in clinical diagnostic criteria for this type of dementia.

Newcastle General

Hospital, Newcastle upon Tyne NE4 6BE

Ian McKeith, senior lecturer in old age psychiatry Andrew Fairbairn consultant in old age psychiatry Robert Perry, consultant neuropathologist

Gateshead Mental Health Unit, Gateshead

Peter Thompson,

consultant in old age psychiatry

MRC Neurochemical Pathology Unit, Newcastle General

Hospital, NE4 6BE

Elaine Perry, senior scientis

Correspondence to: Dr McKeith

BMJ 1992;305:673-8

\section{Introduction}

Behavioural disturbance and mental symptoms are a frequent source of distress to the carers of demented and confused elderly patients. Neuroleptic drugs (major tranquillisers) are frequently used to control such symptoms, exerting their antipsychotic effect via dopamine receptor blockade. Up to $60 \%$ of demented patients in hospital may receive neuroleptics, ${ }^{1}$ and $13 \%$ of elderly people in institutions receive neuroleptics within any 24 hour period. ${ }^{2}$ Despite the lack of methodologically sound trials of neuroleptics in elderly confused and demented patients the use of these drugs for specific target symptoms such as delusions, hallucinations, or severe agitation in dementia has been advocated. Adverse reactions are thought to occur more commonly in subjects with organic brain disease, but it is unclear which diagnostic subgroups, if any, might be at most risk.

Recent surveys of cases of dementia coming to necrops $y^{34}$ have suggested a revision of the proportions attributable to different underlying conditions compared with earlier reports. In up to $20 \%$ of cases there

\section{Operational criteria for senile dementia of Lewy body type}

Fluctuating cognitive impairment affecting both memory and higher cortical functions (such as language, visuospatial ability, praxis, or reasoning skills). The fluctuation is pronounced, with both episodic confusion and lucid intervals, as in delirium, and is evident either on repeated tests of cognitive function or by variable performance in daily living skills

At least one of the following:

Visual or auditory hallucinations or both, which are usually accompanied by secondary paranoid delusions

Mild spontaneous extrapyramidal features or neuroleptic sensitivity syndrome - that is, exaggerated adverse responses to standard doses of neuroleptics

Repeated unexplained falls, or transient clouding, or loss of consciousness, or both

Despite the fluctuating pattern the clinical features persist over a long period (weeks or months), unlike delirium, which rarely persists as long. The illness progresses, often rapidly, to an end stage of severe dementia

Exclusion by appropriate examination and investigation of any underlying physical illness adequate to account for the fluctuating cognitive state

- Exclusion of past history of confirmed stroke or evidence of cerebral ischaemic damage, or both, on physical examination or brain imaging

are neuropathological changes distinguishable from dementia of Alzheimer type or vascular dementia. These can be briefly summarised as the presence of subcortical, limbic, and neocortical Lewy bodies associated with senile plaques, often in the Alzheimer range, but with few or absent neocortical neurofibrillary tangles in most cases. Lewy bodies are inclusion bodies immunoreactive to ubiquitin, probably markers of neuronal distress, and have until recently been considered to be virtually confined to idiopathic Parkinson's disease, in which their distribution is largely subcortical. Patients with the more generalised distribution of Lewy bodies outlined above have been variously described as having senile dementia of Lewy body type,$^{3}$ diffuse Lewy body disease, ${ }^{4}$ or the Lewy body variant of Alzheimer's disease (LBV). ${ }^{5}$ Senile dementia of Lewy body type was the second most common (19\%) neuropathological diagnosis in a series of elderly demented patients dying in hospitals in Newcastle upon Tyne between 1982 and 1987, only dementia of Alzheimer type occurring more commonly $(52 \%)$.

The clinical syndrome associated with senile dementia of Lewy body type has been recorded from the notes of cases confirmed at necropsy, and operational criteria have been generated (see box). ${ }^{6}$ The 
characteristic presentation is of a fluctuating confusional state, for which no adequate underlying medical cause can be found, with associated hallucinations, which are usually visual, and delusions. Mild extrapyramidal features may occur in a proportion of patients at presentation.

A previous comparison of the notes of cases of Lewy body type and Alzheimer type dementia confirmed at necropsy suggested that $57 \%$ of patients with Lewy body type dementia who received neuroleptic drugs showed exaggerated adverse reactions, in some cases reminiscent of the neuroleptic malignant syndrome. ${ }^{6}$ No such reactions were seen in the patients with Alzheimer type dementia. The duration of illness in Lewy body type dementia was less than half of that of Alzheimer type dementia. Although this may simply reflect the natural course of the illness, a comparison of mean survival times suggested that the subgroup of patients reacting adversely to neuroleptics had a significantly shorter survival from the time of presentation to psychiatric services than other patients with Lewy body type dementia. This raises the possibility of increased fatality being associated with administration of neuroleptics in at least some patients.

We describe the outcome of administration of neuroleptics to a second series of patients with Lewy body type senile dementia confirmed at necropsy and of survival analysis performed to determine the hazard ratio in patients with severe sensitivity to neuroleptics.

\section{Patients and methods}

We compared 20 elderly demented patients dying in hospital who had Lewy body type senile dementia confirmed at necropsy since 1990 (including four patients with an initial clinical diagnosis of idiopathic Parkinson's disease), who represented all such cases during that period for whom detailed clinical records were available, with 21 patients with Alzheimer type dementia confirmed at necropsy randomly selected from the Newcastle brain bank register. Details of neuropathological methods and diagnostic criteria have been published.

All patients had received comprehensive psychogeriatric assessment in specialist units, and detailed case notes were available from time of first presentation

TABLE I-Incidence of symptoms in Lewy body type and Alzheimer type dementia. Figures are numbers (percentages) of patients

\begin{tabular}{lcccccc}
\hline & \multicolumn{2}{c}{ At presentation } & & \multicolumn{2}{c}{ At any stage } \\
& $\begin{array}{c}\text { Alzheimer type } \\
(\mathbf{n}=21)\end{array}$ & $\begin{array}{c}\text { Lewy body type } \\
(\mathbf{n}=20)\end{array}$ & & $\begin{array}{c}\text { Alzheimer type } \\
(\mathbf{n}=21)\end{array}$ & $\begin{array}{c}\text { Lewy body type } \\
(\mathbf{n}=20)\end{array}$ \\
\hline Fluctuating cognitive impairment & $1(5)$ & $17(85)^{\star \star}$ & & $1(4 \cdot 8)$ & $18(90)^{\star \star}$ \\
Visual hallucinations & $4(19)$ & $11(55)^{\star \star}$ & & $4(19 \cdot 1)$ & $16(80)^{\star \star}$ \\
Auditory hallucinations & 0 & $6(30)^{\star \star}$ & & 0 & $9(45)^{\star \star}$ \\
Delusions & $4(19)$ & $13(65)^{\star \star}$ & & $4(19 \cdot 1)$ & $16(80)^{\star \star}$ \\
Repeated unexplained falls & $3(14)$ & $7(35)^{\star}$ & & $5(23 \cdot 8)$ & $10(50)^{\star}$ \\
Transient losses of consciousness & $1(5)$ & $5(25)^{\star}$ & & $5(23 \cdot 8)$ & $5(25)$ \\
\hline
\end{tabular}

${ }^{\star} \mathrm{p}<0 \cdot 1,{ }^{\star \star} \mathrm{p}<0 \cdot 05$, compared with Alzheimer type (Fisher's exact test).

TABLE II-Cumulative incidence of extrapyramidal features and neuroleptic exposure in Lewy body type and Alzheimer type dementia. Figures are numbers (percentages) of patients

\begin{tabular}{lcc}
\hline & $\begin{array}{c}\text { Alzheimer type } \\
(\mathbf{n}=21)\end{array}$ & $\begin{array}{c}\text { Lewy body type } \\
(\mathbf{n}=20)\end{array}$ \\
\hline Extrapyramidal features at presentation & $1(5)$ & $9+(45)^{\star \star}$ \\
Receiving neuroleptics at presentation & $1(5) \ddagger$ & $5(25)\|\|^{\star}$ \\
Ever receiving neuroleptics & $14(67)$ & $16(80)$ \\
Developing extrapyramidal features for first time after receiving & $3(21)$ & $7(46)$ \\
$\quad$ neuroleptics (\% of those exposed) & $4(29)$ & $13(81)^{\star}$ \\
With neuroleptic sensitivity syndrome & $3(75)$ & $7(54)$ \\
Mild syndrome & $1(25)$ & $6(46)$ \\
Severe syndrome & & \\
\hline
\end{tabular}

${ }^{\star} \mathrm{p}<0.05,{ }^{\star \star} \mathrm{p}<0.01$, compared with Alzheimer type (Fisher's exact test).

†Four presenting as Parkinson's disease.

fWith no extrapyramidal features.

||One with mild extrapyramidal features. until death. Case notes from nursing homes and information from general practitioners were also sought to ensure that full details of physical and mental state and history of treatment were available. Clinical ratings (by IMcK, AFF) were made blind to detailed neuropathological diagnosis (by RHP). Neuroleptic sensitivity was rated as present if significant adverse effects were recorded after administration of neuroleptics - for example, development or worsening of extrapyramidal features after treatment in the accepted dose range or acute and severe physical deterioration - for which no other adequate cause was apparent, which seemed related in time to the prescription of neuroleptics.

Survival times were calculated both from the time of first symptoms until death (total illness duration) and from first presentation to the psychiatric service until death (duration from presentation). The groups were compared by unpaired $t$ tests, $\chi^{2}$, and Fisher's exact test. Survival of patients with Lewy body dementia in relation to their neuroleptic sensitivity was examined by log rank analysis of actuarial life tables.

\section{Results}

LEWY BODY TYPE VERSUS ALZHEIMER TYPE SENILE DEMENTIA

Patients with Lewy body type dementia were younger than those with Alzheimer type dementia (77 years $(95 \%$ confidence interval $74 \cdot 1$ to $80 \cdot 0) v 81$ years ( 78.6 to 83.9$)$ respectively, unpaired $t=2.249, \mathrm{p}=$ $0.03)$; they were more likely to be male $(13 / 20 v 6 / 21$ respectively, $p=0.023$, Fisher's exact test), and they had a shorter duration of illness $(37.7$ months $(24.9$ to $50.5) v 68.48$ months $(52.0$ to 84.9$)$, unpaired $t=3.07$, $\mathrm{p}=0.004$ ).

Table I shows the frequency of key symptoms rated in each group both at first presentation and also if they ever occurred during the illness. Fluctuating cognitive impairment, visual hallucinations, auditory hallucinations, and paranoid delusions were seen significantly more often in patients with Lewy body type dementia, usually as presenting features. Repeated unexplained falls and transient losses of consciousness were both also more commonly seen.

Table II summarises the incidence of extrapyramidal features in the two groups, both spontaneously occurring and in relation to neuroleptic treatment Nine (45\%) patients with Lewy body type dementia, (including four with an initial diagnosis of Parkinson's disease) and one (5\%) with Alzheimer type dementia had extrapyramidal features at presentation, and in all but one patient with Lewy body type dementia (case 15) these features were rated as predating the prescription of neuroleptics. Sixteen $(80 \%)$ patients with Lewy body type dementia and 14 (67\%) with Alzheimer type dementia eventually received neuroleptics, both groups being exposed to a similarly wide range of drugs (see tables III and IV). Patients with Alzheimer type dementia tended to receive neuroleptics for longer periods, reflecting their longer overall survival time, and also tended to receive a higher dosage.

Sixteen $(80 \%)$ patients with Lewy body type dementia and four (19\%) with Alzheimer type dementia eventually developed extrapyramidal features and these were judged secondary to neuroleptics in all cases in which they were recorded only after presentation.

\section{NEUROLEPTIC SENSITIVITY}

Thirteen (81\%) patients with Lewy body type dementia treated with neuroleptics showed neuroleptic sensitivity as defined above (cases 1-13) compared with four $(29 \%)$ of those with Alzheimer type dementia (cases 1-4) $(p=0 \cdot 04$, Fisher's exact test). Tables III and 


\begin{tabular}{|c|c|c|c|c|c|c|c|}
\hline $\begin{array}{l}\text { Case } \\
\text { No }\end{array}$ & $\begin{array}{l}\text { Age } \\
\text { (sex) }\end{array}$ & Drug and daily dose ${ }^{\star}$ & Route & Duration & $\begin{array}{l}\text { Total } \\
\text { dose } \\
(\mathrm{mg})\end{array}$ & Clinical observations & $\begin{array}{l}\text { Extrapyramidal } \\
\text { features before } \\
\text { neuroleptics }\end{array}$ \\
\hline \multicolumn{8}{|c|}{ Severe neuroleptic sensitivity } \\
\hline 1 & $77(M)$ & $\begin{array}{l}\text { Thioridazine } 25-75 \mathrm{mg} \\
\text { Haloperidol } 1-6 \mathrm{mg}\end{array}$ & $\begin{array}{l}\text { Per os } \\
\text { Per os }\end{array}$ & $\begin{array}{l}7 \text { Weeks } \\
18 \text { Days }\end{array}$ & $\begin{array}{r}2450 \mathrm{mg} \\
32 \cdot 5 \mathrm{mg}\end{array}$ & $\begin{array}{l}5 \text { Days after haloperidol became oversedated with increased tone, neck } \\
\text { rigidity, and bradykinesia. Bedfast; died of pneumonia within } 2 \text { weeks }\end{array}$ & Yes \\
\hline 2 & $83(M)$ & $\begin{array}{l}\text { Thioridazine } 25 \mathrm{mg} \text { twice daily } \\
\text { Trifluoperazine } 1 \mathrm{mg} \text { twice daily } \\
\text { Trifluoperazine } 2 \mathrm{mg} \text { twice daily }\end{array}$ & $\begin{array}{l}\text { Per os } \\
\text { Per os } \\
\text { Per os }\end{array}$ & $\begin{array}{l}3 \text { Days } \\
7 \text { Days } \\
3 \text { Days }\end{array}$ & $\begin{array}{r}150 \mathrm{mg} \\
14 \mathrm{mg} \\
12 \mathrm{mg}\end{array}$ & $\begin{array}{l}\text { Increased agitation and mild parkinsonism with thioridazine, tremor with } \\
\text { trifluoperazine with rapid deterioration after increased dose; died of } \\
\text { pneumonia within } 3 \text { weeks }\end{array}$ & Yes \\
\hline 3 & $87(M)$ & $\begin{array}{l}\text { Haloperidol } 5-10 \mathrm{mgt} \\
\text { Thioridazine } 25-50 \mathrm{mg}\end{array}$ & $\begin{array}{l}\text { Per os } \\
\text { Per os }\end{array}$ & $\begin{array}{l}6 \text { Days } \\
3 \text { Days }\end{array}$ & $\begin{array}{r}65 \mathrm{mg} \\
300 \mathrm{mg}\end{array}$ & $\begin{array}{l}\text { Sudden deterioration after neuroleptics, increased tone, fever }\left(38^{\circ} \mathrm{C}\right) \text {, } \\
\text { creatinine kinase }(1700 \mathrm{U} / 1-\text { reference range } ₹ 175 \mathrm{U} / 1) \text { unresponsive } \\
\text { and unable to swallow; died of pulmonary embolism within } 2 \text { weeks }\end{array}$ & No \\
\hline 4 & $70(\mathbf{M})$ & $\begin{array}{l}\text { Flupenthixol decanoate } 10 \mathrm{mg} \\
\text { Flupenthixol decanoate } 20 \mathrm{mg}\end{array}$ & $\begin{array}{l}\text { Intramuscular } \\
\text { Intramuscular }\end{array}$ & 5 Days & $30 \mathrm{mg}$ & $\begin{array}{l}2 \text { Days after second dose became confused with generalised rigidity, } \\
\text { cogwheeling, and myoclonus. No response to baclofen or dantrolene; } \\
\text { died of pneumonia } 19 \text { weeks later }\end{array}$ & No \\
\hline 5 & $82(M)$ & $\begin{array}{l}\text { Trifluoperazine } 25 \mathrm{mg} \text { twice daily } \\
\text { Trifluoperazine } 2 \mathrm{mg} \text { twice daily } \\
\text { Thioridazine } 2 \mathrm{mg} \text { thrice daily }\end{array}$ & $\begin{array}{l}\text { Per os } \\
\text { Per os } \\
\text { Per os }\end{array}$ & $\begin{array}{l}2 \text { Days } \\
6 \text { Weeks } \\
2 \text { Weeks }\end{array}$ & $\begin{array}{r}100 \mathrm{mg} \\
168 \mathrm{mg} \\
84 \mathrm{mg}\end{array}$ & $\begin{array}{l}\text { Thioridazine caused "paradoxical agitation." Slight increase in tremor } \\
\text { and bradykinesia, became oversedated, salivating and shuffling with } \\
\text { higher dose of trifluoperazine with cogwheel rigidity. Died } 10 \text { weeks } \\
\text { later of bronchopneumonia }\end{array}$ & Yes \\
\hline 6 & $77(\mathbf{F})$ & Haloperidol decanoate $50 \mathrm{mg}$ monthly & Intramuscular & 4 Months & $200 \mathrm{mg}$ & $\begin{array}{l}\text { After fourth injection became drowsy with stiffness in all limbs, gross } \\
\text { tremor of right arm, and difficulty swallowing. Died of pyelonephritis } \\
8 \text { weeks later, immobile and rigid }\end{array}$ & No \\
\hline 7 & $83(\mathbf{M})$ & $\begin{array}{l}\text { Haloperidol } 0 \cdot 5-1 \cdot 0 \mathrm{mg} \\
\text { Haloperidol } 5.0 \mathrm{mg}\end{array}$ & $\begin{array}{l}\text { Peros } \\
\text { Per os }\end{array}$ & $\begin{array}{l}5 \text { Weeks } \\
3 \text { Days }\end{array}$ & $\begin{array}{l}17 \cdot 5 \mathrm{mg} \\
15 \cdot 0 \mathrm{mg}\end{array}$ & $\begin{array}{l}\text { No side effects with low dose; with increased dose became unresponsive } \\
\text { with increased tone with neck stiffness and fever. Remained } \\
\text { semicomatose until death from bronchopneumonia } 4 \text { weeks later }\end{array}$ & No \\
\hline \multicolumn{8}{|c|}{ Mild neuroleptic sensitivity } \\
\hline 8 & $74(M)$ & $\begin{array}{l}\text { Trifluoperazine } 2-5 \mathrm{mg} \text { twice daily } \\
\text { Sulpiride } 200 \mathrm{mg} \text { twice daily }\end{array}$ & $\begin{array}{l}\text { Per os } \\
\text { Per os }\end{array}$ & $\begin{array}{l}8 \text { Weeks } \\
10 \text { Days }\end{array}$ & $\begin{array}{r}196 \mathrm{mg} \\
4000 \mathrm{mg}\end{array}$ & $\begin{array}{l}\text { Cogwheel rigidity and limb stiffness with higher dose of trifluoperazine, } \\
\text { which improved by dose reduction; increased rigidity, no tremor, } \\
\text { restless, and more confused with sulpiride }\end{array}$ & Yes \\
\hline 9 & $73(M)$ & $\begin{array}{l}\text { Thioridazine } 25 \mathrm{mg} \text { twice daily } \\
\text { Haloperidol } 3 \mathrm{mgt} \\
\text { Thioridazine } 50 \mathrm{mg}\end{array}$ & $\begin{array}{l}\text { Per os } \\
\text { Per os } \\
\text { Per os }\end{array}$ & $\begin{array}{l}1 \text { Day } \\
5 \text { Days }\end{array}$ & $\begin{array}{r}50 \mathrm{mg} \\
9 \mathrm{mg} \\
150 \mathrm{mg}\end{array}$ & $\begin{array}{l}\text { On both occasions became acutely bradykinetic, stiff and tremulous, } \\
\text { improved on withdrawal }\end{array}$ & No \\
\hline 10 & $82(\mathrm{~F})$ & $\begin{array}{l}\text { Sulpiride } 200 \mathrm{mg} \\
\text { Sulpiride } 200 \mathrm{mg}\end{array}$ & $\begin{array}{l}\text { Peros } \\
\text { Peros }\end{array}$ & $\begin{array}{l}1 \text { Week } \\
<6 \text { Weeks }\end{array}$ & $\begin{array}{r}1400 \mathrm{mg} \\
<8400 \mathrm{mg}\end{array}$ & $\begin{array}{l}\text { Became confused and parkinsonian on both occasions-masked facies, } \\
\text { stoop, and increased tone persisted after withdrawal }\end{array}$ & No \\
\hline 11 & $66(F)$ & $\begin{array}{l}\text { Sulpiride } 200 \mathrm{mg} \\
\text { Sulpiride } 100 \mathrm{mg}\end{array}$ & $\begin{array}{l}\text { Peros } \\
\text { Peros }\end{array}$ & $\begin{array}{l}4 \text { Days } \\
36 \text { Weeks }\end{array}$ & $\begin{array}{r}800 \mathrm{mg} \\
25200 \mathrm{mg}\end{array}$ & $\begin{array}{l}\text { Tremor and stiffness with higher dose of sulpiride, which resolved with } \\
\text { lower dose }\end{array}$ & No \\
\hline 12 & $79(M)$ & $\begin{array}{l}\text { Haloperidol } 10 \mathrm{mg} \\
\text { Haloperidol } 3 \mathrm{mg} \\
\text { Haloperidol } 0.5 \mathrm{mg} \\
\text { Sulpiride } 100 \mathrm{mg} \\
\text { Haloperidol } 5 \mathrm{mg}\end{array}$ & $\begin{array}{l}\text { Intramuscular } \\
\text { Intramuscular } \\
\text { Per os } \\
\text { Per os } \\
\text { Intramuscular }\end{array}$ & $\begin{array}{l}8 \text { Weeks } \\
8 \text { Days }\end{array}$ & $\begin{array}{r}10 \mathrm{mg} \\
6 \mathrm{mg} \\
1.5 \mathrm{mg} \\
300 \mathrm{mg} \\
15 \mathrm{mg}\end{array}$ & $\begin{array}{l}\text { Mild extrapyramidal features with intermittent dosage. After haloperidol } \\
5 \text { mg intramuscular ( } 3 \text { doses) became sedated, "twitching," and } \\
\text { marked increase in parkinsonism }\end{array}$ & Yes \\
\hline 13 & $78(F)$ & $\begin{array}{l}\text { Thioridazine } 100 \mathrm{mg} \\
\text { Haloperidol uncertain } \\
\text { Trifluoperazine } 2 \mathrm{mg} \text { twice daily }\end{array}$ & $\begin{array}{l}\text { Per os } \\
\text { Per os } \\
\text { Per os }\end{array}$ & $\begin{array}{l}14 \text { Weeks } \\
\text { Uncertain } \\
4 \text { Weeks }\end{array}$ & $\begin{array}{r}9800 \mathrm{mg} \\
112 \mathrm{mg}\end{array}$ & $\begin{array}{l}\text { No extrapyramidal features with thioridazine, notes refer to "develops } \\
\text { severe parkinsonism in response to small doses of haloperidol." } \\
\text { Increased tone noted with trifluoperazine }\end{array}$ & No \\
\hline \multicolumn{8}{|c|}{ No neuroleptic sensitivity } \\
\hline 14 & $69(M)$ & $\begin{array}{l}\text { Haloperidol } 1.5 \mathrm{mg} \\
\text { Trifluoperazine } 5 \mathrm{mg} \text { twice daily } \\
\text { Thioridazine } 75 \mathrm{mg}\end{array}$ & $\begin{array}{l}\text { Per os } \\
\text { Per os } \\
\text { Per os }\end{array}$ & $\begin{array}{l}\text { Uncertain } \\
\text { Uncertain } \\
4 \text { Weeks }\end{array}$ & $2100 \mathrm{mg}$ & $\begin{array}{l}\text { Received haloperidol and lithium, then trifluoperazine for several months } \\
\text { with no extrapyramidal features; later no extrapyramidal features with } \\
\text { thioridazine }\end{array}$ & No \\
\hline 15 & $76(M)$ & $\begin{array}{l}\text { Promazine } 50 \mathrm{mg} \\
\text { Promazine } 100 \mathrm{mg}\end{array}$ & $\begin{array}{l}\text { Per os } \\
\text { Per os }\end{array}$ & $\begin{array}{l}1 \text { Dose } \\
12 \text { Weeks }\end{array}$ & $\begin{array}{r}50 \mathrm{mg} \\
8400 \mathrm{mg}\end{array}$ & $\begin{array}{l}\text { Case notes suggest oversedation after thioridazine } 50 \mathrm{mg} \text { on } 1 \text { occasion; } \\
\text { later tolerated promazine without adverse affects }\end{array}$ & Yes \\
\hline 16 & $72(F)$ & Thioridazine $25-50 \mathrm{mg}$ & Peros & Uncertain & & $\begin{array}{l}\text { Intermittent dosage over several months with no increase in } \\
\text { extrapyramidal features }\end{array}$ & Yes \\
\hline 17 & $73(F)$ & Never received neuroleptics & & & & $\begin{array}{l}\text { Spontaneous extrapyramidal rigidity and gait impairment with } \\
\text { exacerbation and myoclonus on reduction of L-dopa }\end{array}$ & Yes \\
\hline 18 & $87(\mathrm{~F})$ & Never received neuroleptics & & & & No extrapyramidal features & No \\
\hline 19 & $84(F)$ & Never received neuroleptics & & & & $\begin{array}{l}\text { Spontaneous extrapyramidal tremor, dysarthria, and rigidity slowly } \\
\text { progressive over } 8 \text { years }\end{array}$ & Yes \\
\hline 20 & $69(M)$ & Never received neuroleptics & & & & No extrapyramidal features & No \\
\hline
\end{tabular}

^Drugs given sequentially unless indicated otherwise. $†$ Drugs given concurrently.

IV give details of neuroleptic exposure and subsequent clinical observations. In Lewy body type dementia two broad patterns of neuroleptic sensitivity were recognisable. Half of the patients (cases 8-13) showed exaggerated extrapyramidal symptoms within a short period of receiving neuroleptics, which were reversible either by reducing the dose or stopping the treatment or by use of anticholinergics. These, usually acute, reactions were characteristically described in the case notes as "parkinsonism," revealing no further information about the presence or absence of individual extrapyramidal features.

Fifty four per cent of patients with Lewy body type dementia (cases 1-7) and one patient with Alzheimer type dementia (case 1) were judged as showing severe reactions which seemed to precipitate their terminal decline. These severe sensitivity reactions were characterised by a sudden onset of sedation, increased confusion, rigidity, and immobility. Three patients with Lewy body type dementia (cases 3,4 , and 7 ) had features suggesting the neuroleptic malignant syndrome, with fever (cases 3 and 7 ), generalised rigidity (case 4), and raised serum creatinine kinase (case 3; not estimated in any other patients); in the four other cases of Lewy body type dementia and the case of Alzheimer type dementia the notes simply referred to acute and severe parkinsonism with rapid progression. Death occurred between two and 19 weeks after these reactions due to the complications of immobility or reduced food and fluid intake, or both.

\section{SURVIVAL ANALYSIS}

The seven patients with Lewy body type dementia with severe neuroleptic sensitivity did not differ in age from the remainder of the group (unpaired $t=1 \cdot 526$, $p=0 \cdot 14$ ), sex, the presence of hallucinations, delusions, falls, losses of consciousness, or presence of spontaneous extrapyramidal features at presentation (Fisher's exact test). Their mean total duration of illness tended to be shorter at $29 \cdot 3(5 \cdot 7$ to $52 \cdot 9)$ months compared with $42 \cdot 2(25 \cdot 3$ to $59 \cdot 2)$ months for the remainder of the group, as was mean survival from presentation, $9.6(2.64$ to 16.5$) v 25.8(11.5$ to 40.0$)$ months. These figures were further examined by survival analysis.

The figure (top) shows the cumulative probability of death, based on an actuarial life table calculated at annual intervals from first onset of symptoms in the seven patients with Lewy body type dementia with severe neuroleptic sensitivity compared with that in the remaining 13. Two patients died in the first year interval, both in the severely sensitive group, but this was not significant ( $p>0.05$, Fisher's exact test). Log rank analysis showed a hazard ratio $(R)$ at two years of 
$2.31(1.9$ to 7.52$) ; \chi^{2}=1.95, \mathrm{p}>0.05$, but this was not sustained after five years $\left(\mathrm{R}=1 \cdot 18(-1 \cdot 14\right.$ to $2 \cdot 04) ; \chi^{2}=$ $0.35, \mathrm{p}>0.05$.

The figure (bottom) shows a similar comparison for survival from first presentation to psychiatric services calculated six monthly. Three patients died within the first period ( $p=0.031$, Fisher's exact test). The hazard ratio at one year was $2.70(2.50$ to 8.89$) ; \chi^{2}=2.68, \mathrm{p}=$ 0.05 and at three years $2.09(1.96$ to 4.96$) ; \chi^{2}=3.0$, $\mathrm{p}<0.05$. This indicates a significant early increase in mortality which has an overall effect of reducing survival from the time of presentation in the group with severe neuroleptic sensitivity.

\section{Discussion}

It should be emphasised that a study of this type essentially generates a hypothesis rather than producing a conclusive result. None the less, an association between a relatively common but previously underdiagnosed condition, a frequently used intervention, and the possibility of a severe, often fatal, reaction merits serious consideration because of the implications it would have for clinical practice.

As in previous studies of prescribing in demented elderly patients a high proportion of both patients with Lewy body type dementia $(80 \%)$ and those with
Alzheimer type dementia (67\%) received neuroleptic treatment. In patients with Lewy body dementia neuroleptics were usually prescribed to control distressing psychotic symptoms which are common in this group whereas in Alzheimer type dementia they were more often used to reduce agitated or disruptive behaviour. Neuroleptic sensitivity occurred in $81 \%$ of patients with Lewy body dementia who received treatment. In half of these the reactions were severe and were associated with a significant increase in mortality measured from the time of first presentation to psychiatric services, and reflected in a trend towards reduced duration of total illness. Although duration from first onset of symptoms to death is an important clinical measure, the time elapsing between onset of symptoms and referral for assessment and treatment is highly variable. Presentation to psychiatric services can be regarded as a relatively "hard" time point, after which patients are "at risk" of receiving neuroleptics, which may account for the significantly increased hazard ratio in duration from presentation, but not for total duration of illness, for the group with severe neuroleptic sensitivity.

Among the patient variables examined (age, sex, mental state symptoms, or pre-existing extrapyramidal features), none predicted the subsequent development of neuroleptic sensitivity.

TABLE IV-Neuroleptic exposure and adverse responses in patients with dementia of Alzheimer type

\begin{tabular}{|c|c|c|c|c|c|c|c|}
\hline $\begin{array}{l}\text { Case } \\
\text { No }\end{array}$ & $\begin{array}{l}\text { Age } \\
(\text { sex })\end{array}$ & Drug and daily dose $e^{\star}$ & Route & Duration & $\begin{array}{l}\text { Total } \\
\text { dose } \\
(\mathrm{mg})\end{array}$ & Clinical observations & $\begin{array}{l}\text { Extrapyramidal } \\
\text { features before } \\
\text { neuroleptics }\end{array}$ \\
\hline \multicolumn{8}{|c|}{ Severe neuroleptic sensitivity } \\
\hline 1 & $79(M)$ & $\begin{array}{l}\text { Thioridazine } 150 \mathrm{mg} \\
\text { Flupenthixol decanoate } 10 \mathrm{mg} \\
\text { Flupenthixol decanoate } 20 \mathrm{mg} \\
\text { Fluphenazine decanoate } 25 \mathrm{mg}\end{array}$ & $\begin{array}{l}\text { Per os } \\
\text { Intramuscular } \\
\text { Intramuscular } \\
\text { Intramuscular }\end{array}$ & $\begin{array}{l}10 \text { Days } \\
6 \text { Weeks }\end{array}$ & $\begin{array}{r}1500 \mathrm{mg} \\
30 \mathrm{mg} \\
25 \mathrm{mg}\end{array}$ & $\begin{array}{l}\text { Developed marked extrapyramidal features after depot injections } \\
\text { (tremor, bradykinesia, and increased tone) not relieved by } \\
\text { procyclidine. Died of bronchopneumonia } 8 \text { weeks after last dose }\end{array}$ & No \\
\hline \multicolumn{8}{|c|}{ Mild neuroleptic sensitivity } \\
\hline 2 & $81(M)$ & Haloperidol $3 \mathrm{mg}$ & Peros & 20 Weeks & $42 \mathrm{mg}$ & Mild resting tremor, reversible on withdrawal & No \\
\hline 3 & $83(M)$ & $\begin{array}{l}\text { Zuclopenthixol dihydrochloride } 10 \mathrm{mg} \\
\text { twice daily } \\
\text { Thioridazine } 30 \mathrm{mg}\end{array}$ & $\begin{array}{l}\text { Per os } \\
\text { Per os }\end{array}$ & $\begin{array}{l}\text { Uncertain } \\
4 \text { Months }\end{array}$ & $3600 \mathrm{mg}$ & $\begin{array}{l}\text { Reported as becoming parkinsonian with zuclopenthixol } \\
\text { dihydrochloride, which was reversed on withdrawal; maximum } \\
\text { tolerated dose of thioridazine } 30 \mathrm{mg} \text { daily }\end{array}$ & No \\
\hline \multirow[t]{2}{*}{4} & $76(M)$ & Haloperidol $5 \mathrm{mg}$ & Peros & & $10 \mathrm{mg}$ & $\begin{array}{l}\text { Spontaneous mild extrapyramidal tremor exacerbated by single dose } \\
\text { haloperidol } 5 \mathrm{mg} \text { on } 2 \text { occasions }\end{array}$ & Yes \\
\hline & \multicolumn{7}{|c|}{ No neuroleptic sensitivity } \\
\hline 5 & $88(\mathrm{~F})$ & Thioridazine $30 \mathrm{mg}$ & Peros & 3 Months & $2700 \mathrm{mg}$ & No extrapyramidal features & No \\
\hline 6 & $81(\mathbf{F})$ & $\begin{array}{l}\text { Thioridazine } 25 \mathrm{mg} \text { thrice daily } \\
\text { Haloperidol } 0 \cdot 5-3 \mathrm{mg} \text { twice daily }\end{array}$ & $\begin{array}{l}\text { Per os } \\
\text { Per os }\end{array}$ & $\begin{array}{l}\text { 1 Week } \\
4 \text { Weeks }\end{array}$ & $\begin{array}{r}525 \mathrm{mg} \\
42 \mathrm{mg}\end{array}$ & Somnolent with thioridazine, no extrapyramidal features & No \\
\hline \multirow[t]{3}{*}{7} & $76(F)$ & Thioridazine $150 \mathrm{mg}$ & $\begin{array}{l}\text { Per os } \\
\text { Peros }\end{array}$ & 1 Month & $13500 \mathrm{mg}$ & 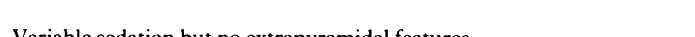 & \\
\hline & & Droperidol $30 \mathrm{mg}$ & $\begin{array}{l}\text { Per os } \\
\text { Per os }\end{array}$ & $\begin{array}{l}\text { 1 Week } \\
2 \text { Weeks }\end{array}$ & $420 \mathrm{mg}$ & Variable sedation but no extrapyramidal features & No \\
\hline & & Haloperidol $10 \mathrm{mg}$ & Peros & 1 month & $300 \mathrm{mg}$ & & \\
\hline \multirow[t]{5}{*}{8} & $75(F)$ & $\begin{array}{l}\text { Thioridazine } 100 \mathrm{mg} \dagger \\
\text { Promazine } 75 \mathrm{mgt}\end{array}$ & $\begin{array}{l}\text { Per os } \\
\text { Per os }\end{array}$ & $\begin{array}{l}16 \text { Weeks } \\
2 \text { Weeks }\end{array}$ & $\begin{array}{r}11200 \mathrm{mg} \\
1050 \mathrm{mg}\end{array}$ & & \\
\hline & & Trifluoperazine $4 \mathrm{mg} \dagger$ & Peros & 40 Weeks & $1120 \mathrm{mg}$ & & \\
\hline & & Haloperidol $3 \mathrm{mg}$ & Per os & 30 Weeks & $630 \mathrm{mg}$ & Variable sedation but no extrapyramidal features & No \\
\hline & & Trifluoperazine $2 \mathrm{mg} \dagger$ & Per os & 10 Weeks & $140 \mathrm{mg}$ & & \\
\hline & & $\begin{array}{l}\text { Haloperidol } 3 \mathrm{mgt} \\
\text { Haloperidol } 1 \mathrm{mg} \dagger\end{array}$ & $\begin{array}{l}\text { Per os } \\
\text { Per os }\end{array}$ & 22 Weeks & $\begin{array}{l}210 \mathrm{mg} \\
154 \mathrm{mg}\end{array}$ & & \\
\hline \multirow[t]{2}{*}{9} & $89(F)$ & Chlorpromazine $50 \mathrm{mg}$ & Per os & 2 Days & $100 \mathrm{mg}$ & Neuroleptics given to control confusional symptoms; died of multiple & No \\
\hline & & Haloperidol 4.5-6 mg & Per os & 4 Weeks & $182 \mathrm{mg}$ & $\begin{array}{l}\text { pulmonary emboli within } 6 \text { weeks with no evidence of extrapyramidal } \\
\text { features }\end{array}$ & \\
\hline 10 & $85(F)$ & Thioridazine $10 \mathrm{mg}$ & Peros & 6 Months & $1820 \mathrm{mg}$ & No extrapyramidal features & No \\
\hline \multirow[t]{6}{*}{11} & $70(\mathrm{~F})$ & Thioridazine $200 \mathrm{mg}$ & Peros & 5 Weeks & $7000 \mathrm{mg}$ & & \\
\hline & & Thioridazine $300 \mathrm{mg}$ & Peros & 6 Days & $1800 \mathrm{mg}$ & Drowsy on higher doses of haloperidol; no extrapyramidal features & \\
\hline & & Haloperidol $20 \mathrm{mg}$ & Per os & 6 Days & $120 \mathrm{mg}$ & & \\
\hline & & Haloperidol $15 \mathrm{mg}$ & Peros & 2 Days & $30 \mathrm{mg}$ & & \\
\hline & & Haloperidol $10 \mathrm{mg}$ & Per os & 2 Days & $20 \mathrm{mg}$ & & \\
\hline & & $\begin{array}{l}\text { Haloperidol } 5 \mathrm{mg} \\
\text { Haloperidol } 2 \mathrm{mg}\end{array}$ & $\begin{array}{l}\text { Per os } \\
\text { Per os }\end{array}$ & 3 Days & $15 \mathrm{mg}$ & & \\
\hline \multirow[t]{4}{*}{12} & $89(\mathbf{F})$ & Thioridazine $50 \mathrm{mg}$ & Peros & 2 Weeks & $700 \mathrm{mg}$ & Drowsv but no extrapyramidal features & No \\
\hline & & Thioridazine $200 \mathrm{mg}$ & Per os & 1 Day & $200 \mathrm{mg}$ & & \\
\hline & & Thioridazine $150 \mathrm{mg}$ & Per os & I Day & $150 \mathrm{mg}$ & & \\
\hline & & Thioridazine $75 \mathrm{mg}$ & Peros & 4 Weeks & $2100 \mathrm{mg}$ & & \\
\hline \multirow[t]{2}{*}{13} & $81(\mathbf{F})$ & Haloperidol $5 \mathrm{mg}$ & Per os & 8 Weeks & $280 \mathrm{mg}$ & No extrapyramidal features & No \\
\hline & & Thioridazine $50 \mathrm{mg}$ & Per os & 11 Months & $13440 \mathrm{mg}$ & & \\
\hline \multirow[t]{2}{*}{14} & $74(F)$ & Chlorpromazine $175 \mathrm{mg}$ & Peros & Uncertain & & No extrapyramidal features & No \\
\hline & & Haloperidol $20 \mathrm{mg}$ & $\begin{array}{l}\text { Per os } \\
\text { Peros }\end{array}$ & $\begin{array}{l}7 \text { Weeks } \\
16 \text { Weeks }\end{array}$ & $980 \mathrm{mg}$ & & \\
\hline 15 & $82(\mathrm{M})$ & Haloperidol $0.5 \mathrm{mg}$ & Per os & Uncertain & & No extrapyramidal features & No \\
\hline 16 & $76(F)$ & & & & & & No \\
\hline 17 & & & & & & & No \\
\hline 18 & 92 & Never received neuroleptics & & & & No extrapyramidal features & No \\
\hline 19 & 77 & & & & & No extrapyramidal ieatures & No \\
\hline $\begin{array}{l}20 \\
21\end{array}$ & $\begin{array}{l}88 \\
84\end{array}$ & & & & & & $\begin{array}{l}\text { No } \\
\text { No }\end{array}$ \\
\hline
\end{tabular}




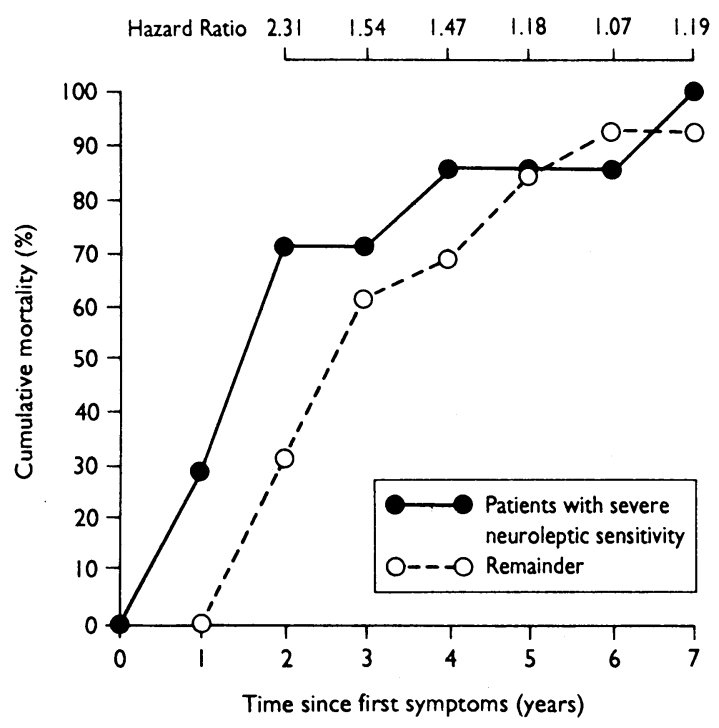

Cumulative probability of death in patients with Lewy body type dementia with and without severe neuroleptic sensitivity. Top: from first onset of symptoms; bottom: from presentation to psychiatric services

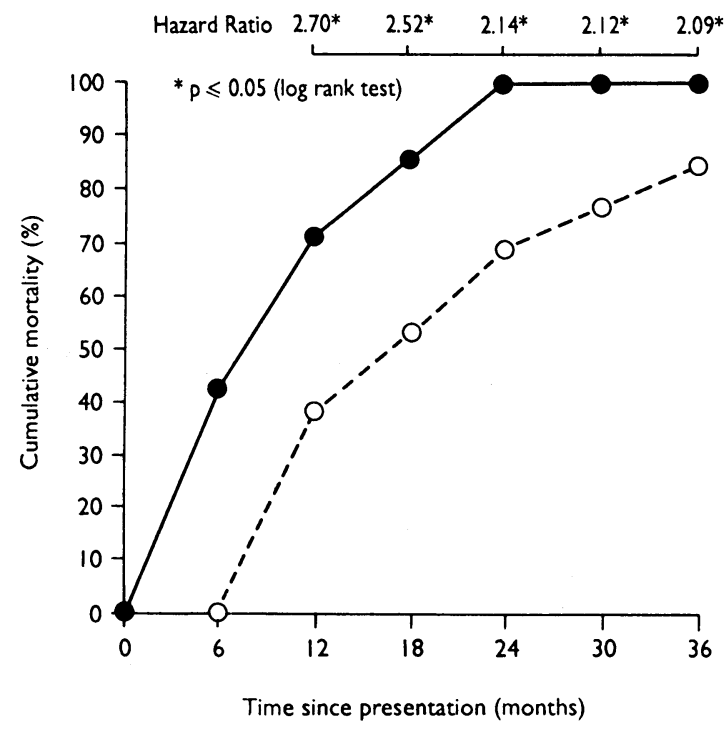

An earlier study of 21 patients with senile dementia of Lewy body type had similar findings, ${ }^{6}$ with $57 \%$ of treated patients showing severe neuroleptic sensitivity and dying within three months of prescription of neuroleptics or an increase in their dose. As yet there are insufficient data to indicate whether particular neuroleptics or routes of administration are more apt to produce adverse reactions. A preliminary observation based on these and the previous findings, however, do suggest that intramuscular administration and depot preparations are implicated in several of these reactions.

\section{METHODOLOGICAL ISSUES}

Various methodological issues need to be considered. The patients selected represented all those with a diagnosis at necropsy of senile dementia of Lewy body type since 1990 matched against randomly selected patients with Alzheimer type dementia. A selection bias probably exists in favour of patients with Lewy body type dementia reaching necropsy since they are more likely to have atypical clinical features. Although this positive bias will inflate prevalence estimates of senile dementia of Lewy body type within the total population with dementia (which this study does not address), it should not affect the estimated frequency of neuroleptic sensitivity within the group with Lewy body type dementia. The patients with Alzheimer type dementia were older, more often female, and had greater neuroleptic exposure due to a combination of longer survival and a tendency to receive a higher dosage. All of these factors might be expected to increase the relative rates of neuroleptic sensitivity in this group; the reverse in fact was observed.

As expected in an elderly group of patients in hospital, several other drugs were being taken by most patients in each group, predominantly analgesics, laxatives, diuretics, minor tranquillisers, and antidepressants. The wide variety of these prescriptions made it impossible to rate their presence or absence in a standard form for analysis, but on inspection they did not seem to be related in any way to the reactions described.

The interpretation of data is complicated not only by the selection and exposure biases outlined but also by the difficulties of assessing clinical state from retrospective case note analysis and the complexity of quantifying neuroleptic exposure over periods of time. Although the case note assessment was blind to detailed neuropathological diagnosis, the assessors inevitably formed opinions about diagnosis based on the clinical history, which in turn may have influenced their interpretation of reactions to neuroleptics.

Our observations are nevertheless highly suggestive of an association between a diagnosis of Lewy body type dementia as opposed to Alzheimer type dementia, neuroleptic treatment, and increased morbidity and mortality. Neuroleptic sensitivity may be a causal factor in this association, but other possibilities must be considered. The natural history in some patients with senile dementia of Lewy body type may be that they enter a terminal phase in which psychotic symptoms and behavioural disturbance are increased. Administration of neuroleptics in response to such deterioration, shortly followed by natural death would also produce the associations we have observed. This hypothesis is not, however, supported by the lack of difference in mental state symptoms seen between the patients with Lewy body type dementia with severe neuroleptic sensitivity and the remainder of this group. Prospective study of a cohort of patients free of neuroleptics will be the only satisfactory way to examine this further.

We propose two types of neuroleptic sensitivity. The milder reactions may be interpreted as the anticipated extrapyramidal side effects of neuroleptic treatment in a population with dementia. Such responses were significantly more frequently seen in the patients with Lewy body type dementia, possibly reflecting a lower dose threshold compared with those with Alzheimer type dementia. Neuroleptic sensitivity of this type may therefore be a diagnostically useful indicator of underyling senile dementia of Lewy body type, hence its inclusion in the clinical diagnostic criteria (box).

Severe neuroleptic sensitivity may be accounted for, in part, by extremes of the milder type, in addition to some idiosyncratic reactions similar to the neuroleptic malignant syndrome. Adozzonizio has argued that the neuroleptic malignant syndrome is greatly underreported in elderly patients, partially owing to the pathoplastic effect of age on presentation but also because of the decreased vigilance for adverse drug reactions in elderly mentally ill patients. ${ }^{8}$

Patients with senile dementia of Lewy body type have neurone counts in substantia nigra which are reduced to $60 \%$ of those for age matched controls and dopamine concentrations in caudate reduced to $40 \%$. $^{7}$ Compromised nigrostriatal dopaminergic transmission may predispose to critical dopaminergic blockade after even modest doses of neuroleptics, particularly since, unlike patients with Parkinson's disease, the presynaptic decrement may be insufficient to cause striatal D2 receptor upregulation. Reduced basal forebrain 
cholinergic activity may also contribute to the observed reactions.

Until clinical operational criteria for diagnosing senile dementia of Lewy body type are validated it is not possible to predict accurately which of the growing number of confused and demented elderly patients may be at increased risk of neuroleptic sensitivity. Probably a significant minority of patients with senile dementia of Lewy body type will erroneously meet currently accepted criteria for a diagnosis of possible Alzheimer's disease and in others there will be a misdiagnosis of vascular dementia. A preliminary evaluation of the proposed clinical criteria for senile dementia of Lewy body type (box) in a mixed population of demented patients indicates a sensitivity of $85 \%$ and a specificity of $96 \%$, with neuropathological diagnosis as the validating criterion (McKeith et al, unpublished data).

Acute confusion and fluctuating cognitive impairment with associated hallucinations and delusions without an identifiable underlying cause typifies some, but not all, presentations of senile dementia of Lewy body type. Patients will potentially be seen in accident and emergency departments; medical, geriatric, and psychogeriatric clinics; and in general practice. A degree of caution may be advised in prescrib- ing neuroleptics for these patients, and if sudden deterioration occurs in such circumstances the possibility of the neuroleptic sensitivity syndrome associated with senile dementia of Lewy body type should be considered. Increased morbidity and mortality are associated with such reactions, the management of which may be similar to that of the neuroleptic malignant syndrome.

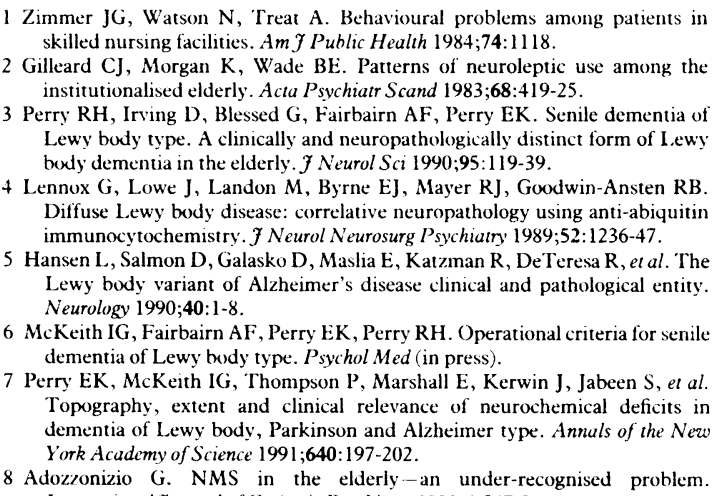

6 McKeith IG, Fairbairn AF, Perry EK, Perry RH. Operational criteria for senile dementia of Lewy body type. Psychol Med (in press).

7 Perry EK, McKeith IG, Thompson P, Marshall E, Kerwin J, Jabeen S, et al. Topography, extent and clinical relevance of neurochemical deficits in dementia of Lewy body, Parkinson and Alzheimer type. Annals of the New York Academy of Science 1991;640:197-202.

8 Adozzonizio G. NMS in the elderly-an under-recognised problem. International Joumal of Geriatric Psychiatry 1991;6:547-9.
Diabetic Retinopathy Unit, Department of Medicine, Royal Postgraduate Medical School,

Hammersmith Hospital, London W12 0NN

Vinod Patel, fuvenile

Diabetes Federation

postdoctoral fellow

Salwan Rassam, clinical

research fellow

Richard Newsom, clinical research fellow

Jutta Wiek, clinical research fellow

Eva Kohner, professor of medical ophthalmology

Correspondence to: Professor Kohner.

\title{
Retinal blood flow in diabetic retinopathy
}

\author{
Vinod Patel, Salwan Rassam, Richard Newsom, Jutta Wiek, Eva Kohner
}

\section{Abstract}

Objectives - $(a)$ To report on the basic parameters of retinal blood flow in a population of diabetic patients with and without retinopathy and nondiabetic controls; (b) to formulate a haemodynamic model for the pathogenesis of diabetic retinopathy from this and other studies.

Design-Laser-Doppler velocimetry and computerised image analysis to determine retinal blood flow in a large cross sectional study.

Setting-Diabetic retinopathy outpatient clinic.

Subjects -24 non-diabetic controls and 76 diabetic subjects were studied (63 patients with insulin dependent diabetes, 13 with non-insulin dependent diabetes). Of the diabetic subjects, 12 had no diabetic retinopathy, 27 had background retinopathy, 13 had pre-proliferative retinopathy, 12 had proliferative retinopathy, and 12 had had pan-retinal photocoagulation for proliferative retinopathy.

Main outcome measures-Retinal blood flow $(\mu \mathrm{l} / \mathrm{min})$ and conductance (rate of flow per unit of perfusion pressure).

Results-In comparison with non-diabetic controls $(9.52 \mu \mathrm{l} / \mathrm{min})$ and diabetic patients with no diabetic retinopathy $(9 \cdot 12 \mu \mathrm{l} / \mathrm{min})$ retinal blood flow was significantly increased in all grades of untreated diabetic retinopathy (background $12 \cdot 13 \mu \mathrm{l} / \mathrm{min}$, preproliferative $15.27 \mu \mathrm{l} / \mathrm{min}$, proliferative 13.88 $\mu \mathrm{l} / \mathrm{min})$. There was a significant decrease in flow after pan-retinal photocoagulation in comparison with all the other groups studied $(4.48 \mu \mathrm{l} / \mathrm{min})$. Conductance of the retinal circulation was higher in the untreated diabetic retinopathy groups. These results were independent of age, sex, type of diabetes, duration of diabetes, glycated haemoglobin concentration, blood glucose concentration, blood pressure, and intraocular pressure.

Conclusions-Retinal blood flow is significantly increased in diabetic retinopathy in comparison with non-diabetic controls and diabetic subjects with no retinopathy. This has implications for controlling hypertension and hyperglycaemia as a strategy in reducing morbidity from diabetic retinopathy.

\section{Introduction}

Diabetic retinopathy remains an important public health concern. In the most definitive epidemiological study to date the yearly incidence of blindness due to diabetes mellitus was found to be 3.3 per 100000 population, or around 1600 cases for England and Wales.' Despite intensive research effort the pathogenic mechanisms important to the initiation and progression of diabetic retinopathy are still poorly understood. It is clear that whatever humoral factors influence the microcirculation it remains to be explained why it is the retina that develops capillary occlusion, exudates, microaneurysms, haemorrhages, and new vessel formation whereas other microcirculations do not. The other important site of microangiopathic insult is the kidney. There the pathogenic mechanisms are becoming clearer as it has become apparent that hyperperfusion of the glomerulus is central to the progression of diabetic glomerulonephropathy. ${ }^{2}$ With the introduction of the laser-Doppler velocimeter developed by Riva $e t$ al it has been possible to measure the velocity of the blood flow in large retinal vessels objectively, reproducibly, and non-invasively. ${ }^{3}$ This together with the determination of vessel diameters by computerised image analysis has allowed a precision in the study of the parameters of retinal blood flow not hitherto possible. We present our study of the haemodynamic changes in diabetic retinopathy in a cross sectional population of diabetic patients.

\section{Subjects and methods}

Twenty four non-diabetic subjects and 76 diabetic patients were investigated (see table I). The nondiabetics were recruited from the departmental staff 